\title{
Quality Regimes in Agro-Food Industries A Regulation Theory Reading of Fair Trade Wine in Argentina
}

\author{
Staricco, Juan Ignacio; Ponte, Stefano
}

\author{
Document Version \\ Accepted author manuscript \\ Published in: \\ Journal of Rural Studies \\ DOI: \\ 10.1016/j.jrurstud.2015.02.002 \\ Publication date: \\ 2015

\section{License \\ CC BY-NC-ND}

Citation for published version (APA):

Staricco, J. I., \& Ponte, S. (2015). Quality Regimes in Agro-Food Industries: A Regulation Theory Reading of Fair Trade Wine in Argentina. Journal of Rural Studies, 38(april), 65-76.

https://doi.org/10.1016/j.jrurstud.2015.02.002

Link to publication in CBS Research Portal

\section{General rights}

Copyright and moral rights for the publications made accessible in the public portal are retained by the authors and/or other copyright owners and it is a condition of accessing publications that users recognise and abide by the legal requirements associated with these rights.

Take down policy

If you believe that this document breaches copyright please contact us (research.lib@cbs.dk) providing details, and we will remove access to the work immediately and investigate your claim. 


\section{Quality Regimes in Agro-Food Industries: A Regulation Theory Reading of Fair Trade Wine in Argentina}

\section{Stefano Ponte and Juan Ignacio Staricco}

Journal article (Post print version)

CITE: Quality Regimes in Agro-Food Industries: A Regulation Theory Reading of Fair Trade Wine in Argentina. / Staricco, Juan Ignacio; Ponte, Stefano. In: Journal of Rural Studies, Vol. 38, No. april, 04.2015, p. 65-76.

DOl: 10.1016/j.jrurstud.2015.02.002

Uploaded to Research@CBS: December २०16

(C) 2016. This manuscript version is made available under the CC-BY-NC-ND 4.0 license http://creativecommons.org/licenses/by-nc-nd/4.0/ 


\section{Quality regimes in agro-food industries: A regulation theory reading of Fair Trade wine in Argentina}

Re-submitted for publication to Journal of Rural Studies

Juan Ignacio Staricco, PhD Fellow, Department of Business and Politics, Copenhagen Business School, Porcelænshaven 24A, 2000 Frederiksberg, Denmark jis.dbp@cbs.dk

Stefano Ponte*, Professor, Department of Business and Politics, Copenhagen Business School, Steen Blichers vej 22, 2000 Frederiksberg, Denmark sp.dbp@cbs.dk

${ }^{*}$ corresponding author

Acknowledgements

An earlier version of this paper was presented at the conference 'Renouveler les approches institutionnalistes sur l'agriculture et l'alimentation: La "grande transformation" 20 ans après', Montpellier, SUPAGR0, 16-17 June 2014. We are grateful for the useful feedback received at this conference, particularly from Robert Boyer, Gilles Allaire and Jean-Marc Touzard. We are also thankful to Lucía Garbarino for the graphic design of Figure 1 and to the two JRS referees for their insightful and constructive criticism. 


\title{
Quality regimes in agro-food industries: A regulation theory reading of Fair Trade wine in Argentina
}

\begin{abstract}
In this article, we examine the transformative potential of changing quality regimes in agro-food industries through the analysis of whether Fair Trade wine in Argentina provides a meaningful economic alternative that goes beyond the impact it has on direct beneficiaries. The wine sector has a long history in valorising a variety of quality dimensions, and has developed one of the most complex and sophisticated quality infrastructures, making it an ideal terrain of analysis. Furthermore, it is going through a major process of restructuring in which the battle-lines are drawn along the application, challenge and reinterpretation of different quality content. Through the lenses of a sectoradjusted version of regulation theory, we show that the Fair Trade wine sector does not substantially deviate from the conventional wine economy in Argentina. Instead of empowering the most vulnerable groups, those producing table wine for the domestic market, Fair Trade is actually further marginalizing them.
\end{abstract}

Keywords: regulation theory, quality regimes, Fair Trade, wine, Argentina 


\section{Introduction}

Fair Trade products have become an important segment of the agro-food industry. The total value of sales has increased dramatically in the past decade or so, from €831 million in 2004 to €4.8 billion in 2012 (Fairtrade Labelling Organizations International, 2005; Fair Trade International, 2013). The Fairtrade Foundation has affirmed that it 'provides a genuine alternative, a means of ensuring that growers benefit as they should from their crops' (Fairtrade Foundation, 2002:13). A deep commitment to the socio-economic sustainability of producers and better terms of international trade are the principles that have guided the architecture of this self-proclaimed alternative economic project.

The now very large literature on Fair Trade shows diverse and complex, but generally positive, social and economic outcomes on farmers' organizations, local livelihoods and adjacent communities in the Global South (Bacon, 2005; Daviron and Ponte, 2005; Raynolds et al. 2007; Le Mare 2008). But the growth and commercial importance of Fair Trade products relies on mainstream retail, thus casting doubts on whether it can be considered an authentic alternative. This issue has been widely debated from a variety of perspectives in the literature. One of the approaches in this debate has been to classify Fair Trade as a new dimension of product quality, to reflect on struggles over its 'civic' or 'ethical' content, and to judge these struggles as for or against a contemporary capitalist project. This project is said to be striving not only to 'commodify' new product qualities but also information about them - what Freidberg $(2003 ; 2004)$ termed 'double fetishism'. These problematic dynamics are said to hollow out Fair Trade and other sustainability labels (among many others, see Barrientos et al. 2007; Dolan, 2010; Raynolds 2002; 2009; 2012; Raynolds et al. 2007; Renard 2003; Rosin and Campbell 2009), and call into question the role of ethical consumption in facilitating socio-economic change (Goodman 2004; 2010).

Wine has been one of the flagship products in discussions over the past and current transformations of quality regimes in the agro-food industry. It has a long history in valorising a variety of quality dimensions, and one of the most complex and sophisticated 'quality infrastructures'. Furthermore, it is going through a major process of restructuring in which the battle-lines are drawn along the application, challenge and re-interpretation of different quality content (Barbera and Audifredi 2012; Barham 2003; Hayward and Lewis 2008; Ponte 2009). Wine is a relatively recent addition to the portfolio of Fair Trade products, having only been certified for the first time in 2003. It has grown dramatically in the past decade, from estimated retail sales of 600,000 liters in 2004 to over 16.4 million liters in 2012 (Fairtrade Labelling Organizations International 2005; Fairtrade International 2013). Fair Trade adds a unique quality dimension to wine produced in the Global South - given that producers in the Global North cannot apply for certification. With the three main producer countries of Fair Trade wine ${ }^{1}$ (South Africa, Chile and Argentina) representing the trendy 'new

\footnotetext{
${ }^{1}$ The current number of Fairtrade certified organizations in wine (Small Producer Organizations, Hired Labour situations and Traders) and their countries of origin are: South Africa, 52; Chile, 14; Argentina, 11; Brazil, 2; Lebanon, 2; and Tunisia, 1 (FLO-CERT, 2014).
} 
world wines', it is expected that the volumes sold and the revenues produced will continue climbing in the near future (Artopoulos et al. 2010).

In this article, we examine whether Fair Trade provides a meaningful economic alternative that goes beyond the impact it has on direct beneficiaries. We do so through a regulation theory approach adapted to the sector level and applied to the case study of Fair Trade wine in Argentina. Regulation theory provides relevant analytical elements that allow a holistic understanding of Fair Trade, helping to explain how it is embedded in a broader economic system, instead of isolating it within a single socio-economic sphere. More broadly, this article is part of an ongoing quest to blend micro-, meso- and macro-approaches towards an understanding of how agro-food industries and value chains are being transformed, and with what consequences for producers in the Global South. In previous work, one of the authors examined how the functioning of agro-food value chains is being shaped by struggles over quality conventions - through the negotiation, arbitration and (re)definition of quality (Gibbon and Ponte 2005; Ponte and Gibbon 2005). The purpose of that kind of analysis was to understand how value chains are driven, and what repercussions struggles over quality conventions have on entry barriers, terms of participation, functional divisions of labour along the chain and distribution of value added - with particular attention paid to the role of sustainability standards and certifications, and related 'civic' content of quality conventions, in these dynamics [references removed]. However, the functioning of the value chain was only partially embedded in the broader framework of socio-economic relations and institutional forms at the national and transnational levels. The analysis of quality conventions at individual nodes of the value chain, and how these travel upstream and downstream, revealed important features of value chain governance and related redistribution effects (Ponte 2009). But the regulatory and institutional factors shaping these value chains were not systemically integrated in the analysis (Ponte and Sturgeon 2014). Rather, they were seen as framework conditions within which internal value chains operations were examined. In this article, we start tackling these limitations by re-engaging with the research agenda of regulation theory (see Allaire and Boyer 1994) as applied to the restructuring of agro-food industries.

In the next section, we briefly summarize some of the main approaches that have been used in the literature to make sense of changing quality regimes in the agro-food industry. In Section 3, we highlight the role that a sector-adjusted version of regulation theory can play to remedy some of the main deficiencies of existing approaches. In Section 4, we apply regulation theory to the case study of Argentinean Fair Trade wine. In the conclusion, we sum up the lessons provided by this case study and provide some directions for future research.

\section{Fair Trade and the wine industry: Existing approaches and their limitations}

The analysis of quality conventions has been often used in the literature to explain the evolution of quality regimes of the agro-food sector. Drawing originally from work by Boltanski and Thévenot (1991), scholars in this field 
have developed a typology of quality conventions that are said to minimize uncertainties about quality in the exchange of products and thus facilitate specific forms of coordination (Eymard-Duvernay 1989; 2006a; 2006b; Ponte and Gibbon 2005; Ponte, 2009; Sylvander 1995; Thévenot 1995). The Anglophone agro-food literature has often applied this framework in attributing one or another type of convention to the disclosure of quality. Much discussion has been focused on the putative content of 'civic conventions' (where Fair Trade is usually placed) and whether these are being folded within a compromise of 'market' and 'industrial' conventions that allows 'alternative' quality traits to be mainstreamed and standardized (Barham 2002; Freidberg 2003; 2004; Kirwan 2006; Raynolds 2002, 2012; Renard 2003). Alternatively, the analysis of quality conventions has been used to highlight the putative emergence of 'alternative food networks' based on locality and domestic conventions (see Murdoch and Miele 1999; Murdoch et al. 2000).

The analysis of conventions has also been applied specifically to understand the dynamics of quality in the wine industry and how quality conventions have shaped production practices, organization and management, and institutional and regulatory innovation (Barbera and Audifredi 2012; Guthey 2008; Lindkvist and Sanchez 2008; Sanchez-Hernandez et al. 2010; Sanchez-Hernandez 2011). Value chain analyses for wine in specific countries (see Cusmano et al. 2010; Gwynne 2006; 2008; Hayward and Lewis 2008; Lewis 2008) are also available, but are only rarely combined with an analysis of quality conventions (for an exception, see Ponte 2009).

In relation to Fair Trade wine, the existing literature is mainly concerned with the experience of South Africa ${ }^{2}$ (Herman 2010; 2012; Kruger and du Toit 2007; McEwan and Bek 2009a; Moseley 2008), with only one contribution on Chile (Kleine 2008) and none on Argentina so far. Kleine (2008) provides an optimistic take on Fair Trade wine. Her action-oriented research project in Chile examined the implementation of an internet interface and a traceability system that allow actors in the value chain to retrieve economic, social and environmental information about specific wines. Her argument is that Fair Trade certification provides producers and the certification body with 'moral power' over other actors in the value chain, thus weakening the power of supermarket chains. The positive role of 'more information' is also appreciated by Herman (2010), who engages with the 'double-fetishism' argument (originally raised by Freidberg 2003; 2004) in her examination of Fair Trade wine in South Africa. She argues that while the use of a standardized label acts as a substitute for engaged knowledges, a 'politics of reconnection' poses dilemmas and challenges to Fair Trade - given that its mainstreaming strategy is 'based on a simplified and standardized mark so as to build consumer awareness and decrease confusion in an increasingly crowded marketplace' (ibid.: 418). Yet, she concludes that providing more information per se is positive, as it can lead to 'questioning by consumers and an appreciation of producers' (ibid.). She also argues that Fair Trade (combined with a 'black economic empowerment' discourse) in South

${ }^{2} \mathrm{~A}$ related literature looks at other ethical trade and 'black economic empowerment' initiatives in the wine industry in South Africa (Bek et al. 2007; du Toit et al. 2008; McEwan and Bek 2006; 2009b). 
Africa offers participants significant 'opportunities to overcome continuing structural constraints that impact on their everyday lives' (Hernan 2012: 1129).

Moseley (2008) is relatively optimistic on the potential of Fair Trade for social transformation in South Africa as well, but also underlines that it 'does not guarantee a change in social relations if the new owners of production (workers in this case) do not have the skills, confidence, legal support, and contacts to successfully run such a business' (ibid.: 303). More critically, McEwan and Beck (2009a), highlight that 'the threat to the radical potential of social and environmental certification schemes lies in the distinction between the corporate ethical discourse and the moral experience of workers' (ibid.: 264) and that 'despite proliferation of codes, standards and certifications, very little is likely to change in the lives and conditions of work for farm workers' (ibid.).

As this short summary suggests, much of the literature focuses on the impact of Fair Trade on putative beneficiaries in the wine industry. This is of course an important aspect, but it is also necessary to know what the impact of Fair Trade is on other actors in the same sector, who may be fighting for survival against more capitalized and often transnational players, as we will show below. In our contribution, we complement this literature by comparing Fair Trade with the wine industry more generally, and by examining how both are embedded in the broader political economy (of Argentina). By examining how Fair Trade impacts also on non-participants, and how it is inserted in sectoral and national political economies, we seek to provide a more holistic view of the potential and limitations of Fair Trade.

\section{Regulation theory redux: A sectoral approach}

Regulation theory (RT) understands social reality as an ensemble of contradictory social relations and makes of their institutionalization, crisis and change its main object of study (Billaudot 1996: 32). From this perspective, prolonged accumulation appears to be the exception rather than the rule, and becomes possible only when the struggle inherent to contradictory social relations can be channeled in specific ways. It is with the aim of understanding these exceptional moments of stability and growth that RT has developed its main analytical concepts.

RT uses the notion of regime of accumulation to describe a long-term macroeconomic situation in which the transformations in the conditions of production and consumption evolve in a complementary pattern (cf. Lipietz 1983: xvi; 1988: 31). Stabilized regimes of accumulation are the result of 'the specific coercive effects of institutional forms which manage to create a coherence of strategies and expectations among agents living in a capitalist market economy' (Lipietz 1988: 32). The key for stability in a regime of accumulation relies on the emergence of an efficient mode of regulation - a relatively coherent combination of compatible institutional or structural forms that are able to adjust, guide or coerce individual and social behavior (cf. Boyer and Saillard 2002: 64; Lipietz 1983: xvi-xvii;). When a regime of accumulation is 
successfully combined with a mode of regulation, they give rise to a mode of development (Boyer and Saillard 2002: 64).

A mode of regulation is shaped by the conjunction of a group of relatively coherent institutional or structural forms that become relevant in specific societies at specific times in history (cf. Boyer 1990: 17, 37; Boyer and Saillard 2002: 61). Most RT authors agree that the relations of exchange and production typical of capitalism are mainly made viable and normalized by three institutional forms: the wage relation, a monetary regime and a form of competition. These three forms express, respectively: the way in which surplus value is appropriated; how economic units are connected; and the pattern of relations between the centers of accumulation (Boyer 1990: 37). Two other relevant structural or institutional forms are also relevant: the state and the mode of insertion in the international context (Boyer 2004).

While our goal is to assess Fair Trade's specificities and impact as observed in the Argentinean wine industry, the original RT concepts were developed from a macroeconomic point of view. Consequently, the challenge is how to adapt these to the agro-food sector. Bartoli and Boulet (1990) highlighted two main risks in adapting concepts that were originally developed at the macroeconomic level to a sectoral scale. One risk is to mechanically transpose concepts from one level to the other - a general mode of regulation would be imposed to different sectors, simply reproducing the overall pattern without expressing any specificity. The other risk is to consider sectors as the primary level of regulation, assuming that regimes of accumulation and structural forms originate and find their coherence within them. Such an approach would not take into account the interdependence and possible domination exercised by the more general levels of capital accumulation and social reproduction (ibid.: 18). In their attempt to elaborate a regulationist conceptualization of sectors that is capable of avoiding both risks, Bartoli and Boulet proposed to begin with the hypothesis of the existence of a specific sectoral mode of regulation and, in order to account for it, a series of sector-adjusted analytical categories. However, any conclusions on the nature and significance of the sectoral mode of regulation are not presumed theoretically for Bartoli and Boulet, but left to the empirical case-by-case analysis.

Building on, but also expanding, Bartoli and Boulet's analysis of the literature, Boyer (1990) described four different ways in which a sectoral (agricultural) mode of regulation can be analyzed. First, one could project the global level into the sectoral one. From this perspective, the changes that occurred in agriculture during the 1960s would have been a result of the adoption of the logic and structural forms characteristic of Fordism, thus suggesting a correspondence between sectoral and broader modes of regulation. Second, one could acknowledge the specificities of the agricultural sector, but explain them from a functionalist point of view, in terms of a necessity imposed by the broader level of accumulation and regulation. Third, one could argue for the existence of specific institutional regimes in sectors, which enjoy relative autonomy from the overall regime of accumulation (as Bartoli and Boulet 1990 do). While Boyer criticizes the first two approaches on the basis that they are unable to 
acknowledge any sectoral specificity, he sees the third as overestimating the autonomy of the sector and its originality. As an alternative, Boyer $(1990 ; 1994)$ proposes a fourth synthetic approach, which considers the sectoral mode of regulation as the result of the combination of sector-specific institutional dispositifs and their articulation within a macro mode of regulation. This approach is expected to solve the tension in the macro/sectoral divide by recognizing agriculture as a specific but not autonomous sector.

In Allaire and Boyer's edited collection (1994), which brings together regulationist and conventionalist readings of the transformation of agriculture, Boyer introduces the first examples of empirical research guided by such a synthetic approach and calls for the further development of sector-adapted regulationist analyses. This influence can be detected in Lacroix et al. (1994), who postulate the inadequacy of the 'wage relation' form for the agricultural domain and propose to replace it with the 'social work relation' in order to truly grasp the labor-capital relation in agriculture. It is also evident in Touzard's (1994) proposal of overcoming the state as the necessary frame for regulation and instead focus on sectors and regions. In following years, however, the RT debate on the agricultural sector has been relatively muted. Even in Laurent and $\mathrm{du}$ Tertre's edited collection (2008) on the processes of re-sectoralization and re-territorialization of regimes of accumulation and modes of regulation, only one chapter is dedicated to the agricultural sector.

We inscribe our contribution in relation to Touzard's more recent call for reengaging with RT in view of a 'renewal of political debates on the agro-food sector, the diversity of its models an trajectories, [and] the need to understand the evolution of its specificities and crises' (Touzard 2009: 1930; translation by the authors). In our article, we seek to engage with the approach initiated by Bartoli and Boulet (1990), but also build on Boyer's criticism indicating that a sectoral mode of regulation overestimates the autonomy of the sectoral level from broader forces operating in the larger economy. We therefore respond to Boyer's (1990) call for an approach that conceptualizes the sectoral mode of regulation as a specific form embedded in an overall mode of regulation. At the same time, our contribution to Boyer's synthetic approach pursues a different analytical strategy: while Bartoli and Boulet (1990:11) rejected the possibility of resorting to the traditional structural forms when analyzing a sector, we stick to the existing macro-level RT concepts. This is because our point of departure is not a sectoral mode of regulation as an entity per se, but a sector (the empirical features of the wine industry) as the meeting point between a macro mode of regulation and the particular regulatory elements that are sector-specific. In this way, the sectoral mode of regulation does not emerge as an autonomous and differentiated body, but it is better understood as a specific form of the broader mode of regulation.

RT acknowledges that the dominant position of a mode of regulation does not eliminate the possibility of a coexistence of alternative or subordinated modes of regulation within a same social formation (cf. Lipietz 1988: 34; Jessop 1997: 311). However, when it comes to the analysis of Fair Trade within the wine sector, this article does not attempt to prove or refute the existence of a Fair 
Trade sub-mode of regulation. Instead, our goal is to use the main concepts provided by RT as heuristic tools in order to: (1) characterize and compare Fair Trade vis-á-vis the conventional mode of regulation in the wine sector; and (2) analyze the impacts of Fair Trade as coupled with the sectoral regime of accumulation. These two analytical steps, mediated by regulationist concepts, make it possible to assess whether Fair Trade actually provides a meaningful economic alternative in the Argentinean wine sector.

\section{Methodology}

Regulation theory's main concepts drove our methodological choices - we used them as heuristic tools to select what aspects of the conventional economy and of Fair Trade to analyze. We applied the concept of 'regime of accumulation' first to the Argentine economy, and then to the specificities of the wine sector. To provide a general picture of the overall regime of accumulation in Argentina, we examined secondary sources and traced its evolution in the past three decades. In relation to the regime of accumulation in the wine industry, we drew from the existing literature on the restructuring of this sector in Argentina and triangulated it with data obtained through interviews with sectoral organizations, key informants, winery managers and grape growers. To assess Fair Trade's degree of transformative potential, we applied the RT concept of 'mode of regulation' to the wine sector and sought to compare two distinct modes: conventional and Fair Trade. This analysis was guided by the five institutional forms suggested by RT, which provided us with useful criteria not only to describe its main characteristics, but also to develop a comparative framework.

[Figure 1 here]

The RT grid of concepts constituted our analytical map in the process of data collection. Most of the empirical data presented in this article was collected through fieldwork by one of the authors between August and December 2013 in Argentina (mainly in the wine producing region of Mendoza, but also in La Rioja - see Figure 1). These included 45 in-depth, semi-structured interviews with relevant actors (certified and non-certified wineries, grape growers and traders, farm and winery workers, sectoral institutions, relevant state agencies, Fair Trade representatives, and a FLO-CERT auditor). Most interviews lasted between 45 minutes and an hour, and mainly focused on questions that could help us understand how the industry's wage relation, logic of competition, money form, state intervention and international insertion were articulated and in which ways Fair Trade provided alternatives, if any. The actors' accounts of their experiences were contrasted with information obtained from documentary sources. Two categories of documents proved to be most relevant: (1) national and provincial legislation and industry regulations, which provided the official frame for many aspects of the conventional mode of regulation; and (2) Fairtrade's mandatory standards, which offered a description of how a Fair Trade mode of regulation should look like. Additionally, official documents by Fairtrade International were analyzed to understand its goals and strategies. 
The first step in data analysis was a thorough reading of all transcripts of interviews and relevant documents, and coding related to the five institutional forms. The second step was a re-organization and re-coding of interview fragments according to which aspect of each institutional form they were referring to. The third step was to aggregate the relevant aspects of each institutional form to describe a conventional mode of regulation and a Fair Trade mode of regulation. As we sifted through the data, we found it useful to further distinguish, within the Fair Trade mode of regulation, between how different aspects are presented in the standard and how they are applied in practice. The resulting grid is represented in Table 1.

[Table 1 here]

\section{Case study: Fair Trade wine in Argentina}

In this section we apply the approach outlined above to the case study of the wine industry in Argentina. First, we provide a brief picture of the main features of the industry. Second, we outline the regimes of accumulation that have characterized the Argentinian economy and its wine sector in the past three decades, and the relations between them. Third, we examine the mode of regulation of conventional wine, followed by the analysis of the mode of regulation of Fair Trade wine (see summary in Table 1).

\subsection{Main features of the Argentinean wine industry}

Argentina is the world's $5^{\text {th }}$ biggest producer of wine, behind France, Italy, Spain and the United States (OVI, 2011). While it was historically a country with high levels of wine consumption, in the last three decades it has witnessed a rapid decrease of the consumption/production ratio, to the point that the International Organization of Vine and Wine has changed its classification from a net consuming to a net exporting country (OVI 2009). This change has been accompanied by a paradigmatic shift in the industry, which has begun to produce fine wines specifically for the international market. This has divided the industry not only economically (between an export-oriented and dominant sector on one side, and a traditional and weaker sector on the other) but also geographically, with the historic wine producer region of Mendoza monopolizing wine exports. It is within this trend towards the expansion into the export market that some wineries have begun seeking Fair Trade certification. While the number of certified actors is still limited (11), it makes Argentina the third largest Fair Trade certified wine producer in the world.

\subsection{Regimes of accumulation at the macro and sectoral levels}

At the macroeconomic level, the period between 1989 and 2002 in Argentina was characterized by a mode of development combining: (1) a 'competitive' mode of regulation based on currency convertibility, and (2) a 'semi-intensive' regime of accumulation dominated by foreign capital and productivity gains achieved through improvements of production techniques and the reorganization of the productive process (Neffa and Panigo 2010). The main goal 
of this mode of development was to increase the rate of profit of private firms in order to encourage private investment, which was expected to be the engine behind GDP growth. An important strategy to do this was the flexibilization in the organization of companies, production and work, with the goal of increasing productivity, reducing costs, and moderating wage increases and expenditures in indirect wages. The hyperinflation that occurred by the end of the 1980s was tackled by establishing a 1:1 convertibility between the Argentinean peso and the US dollar. The deficit in the balance of trade resulting from the overvaluation of the peso was expected to be compensated by attracting foreign direct investment (FDI). In order to promote FDI, the government eliminated all controls on incoming and outgoing capital flows and guaranteed a nondiscriminatory treatment of all foreign capital.

Argentina used to be a country with high volumes of production and consumption of wine. During most of its history, the local wine industry was structured around a regime of accumulation characterized by many as 'productivist' (Azpiazu and Basualdo 2003; Bocco et al. 2007; Mateu 2007), consisting of making low-quality table wine for mass local consumption - with exports to neighboring countries having a marginal role and access to more distant markets depending on sporadic opportunities. While constant downturns have always been a distinctive feature of this sector, the crisis that took place between the early-1970s and late-1980s was of major significance. During this time the industry not only faced the usual problem of oversupply, but also constantly diminishing local consumption. The growing prestige and increasing demand for 'new world wines' in some of the main consumption markets in Europe and North America offered an opportunity for Argentinean producers to enter the global wine market. However, in order to do so a radical process of conversion was needed. It was necessary to move from the traditional production of table wine for the local market to the adoption of new winemaking techniques that matched the wine taste of overseas consumers.

The point of departure for this process of conversion was a new conception of the product around which the industry was subsequently re-built. While previously accumulation was determined by quantity, the new focus on fine wine set new parameters focused on quality. Profits were accrued not by growing volume of sales, but by upgrading quality and unit value. This meant a movement away from the making of generic wines towards varietal-based wines, thus the adoption of new infrastructure and techniques. The new quality imperatives in wine production also led a radical transformation in viticulture more generally, in terms of varieties planted, grape characteristics and labour organization.

Favored by the deregulation of capital markets, the elimination of taxes on stock exchange transactions, and the possibility of accruing profit in dollars, the conversion of the local wine industry was first boosted mainly by foreign capital and then followed by the establishment of large national groups. International capital focused mainly on converting pre-existing wineries and on producing fine wines for the export market. These changes were made possible by the acquisition of new technologies and the modernization of already existing ones, together with the introduction and diffusion of advanced winemaking 
techniques. The introduction of more sophisticated technology was favored by the fixed exchange rate that made imports relatively inexpensive. The process of conversion also concerned the viticulture sector, with the implementation of a 'scientific approach' based on rationalization and technification of viticultural practices. These posed great challenges to traditional producers not only in terms of the investments required, but also in terms of a new work logic.

Neffa and Paniago's (2010) periodization of Argentina's macroeconomic history uses 2002 as a landmark, when the mode of development constituted by a 'competitive' mode of regulation and a 'semi-intensive' regime of accumulation started being replaced by one combining an 'administered' mode of regulation (characterized by wage determination through collective bargaining and growing state investment) and an 'extensive' regime of accumulation (mainly based on the expansion of agricultural areas facilitated by high commodity prices, and the relative stagnation of productivity). This period was marked by the maxi-devaluation of 2002 (by approximately 300\%) and the replacement of currency convertibility with a system of multiple exchange rates (governed by differential retentions on specific exportable products). It also witnessed high rates of GDP growth (until 2008) led by an export boom in primary products and some industrial manufactures, and the rise in the production of intermediate and final goods.

While the two modes of development pre- and post-2002 were very different at the macro level, they complemented each other in the process of conversion of the wine industry. In the 1990s, the overvaluation of the peso, deregulation and the absence of capital controls provided a favorable context for the recapitalization of the wine industry. While this led to relatively important increases in exports, the overvalued exchange rate made Argentinean wines uncompetitive internationally. It was indeed only with the devaluation of 2002 that the wine industry started experiencing a boom in exports.

The process of conversion has been driven mainly by wineries. They have moved from an almost exclusive focus on winemaking to leading a major revolution in viticultural practices as well. This took place through the establishment of own vineyards, cooperation with semi-independent producers, and by assuming an active role in the areas of commercialization and international trade. This has resulted in a duality between: (1) a marginalized sector dominated by five major wineries that make, blend and commercialize wine and represent the only business opportunity for low-quality and low-productivity grape producers; and (2) a now dominant sector controlled by foreign capital and selected domestic groups with international orientation, which focus on improving quality, productivity and marketing.

\subsection{Mode of regulation: conventional wine}

\subsubsection{Wage relation}

The wage relation is the structural form that has experienced the most important transformation in the transition from one regime of accumulation to the other. 
While historically small grape producers worked in their fields with their families, the growth of grape cultivation areas entailed the need to hire farm workers. Since the XIX century, the dominant kind of worker had been the 'contratista'. A contratista is considered from a legal perspective an 'atypical and subordinated worker', who is both a wage earner but also a small entrepreneur. A contratista does not own any land and works in someone else's vineyard. The owner is in charge of providing all inputs and tools to carry out the work, but the contratista has an autonomous status and organizes the activities and work over the land under his/her responsibility. The person who hires a contratista is responsible for providing him/her with a house within the farm and for paying a small salary for ten months a year, plus contributions to social security. The biggest income for contratistas accrues from the percentage of the harvest that they receive (ranging by law from $15 \%$ to 19\%). This form of work (which by the end of the 1980s was still responsible for $30 \%$ of the cultivated surface; Poblete 2012) was seriously affected by the emergence of the new regime of accumulation we highlighted above.

The introduction of new technologies and management systems in the wine industry brought a modest decrease in the amount of working hours per hectare needed (Neimand and Bocco 2001) but, more importantly, a qualitative change in the skills required. The process of conversion brought a reduction in the number of permanent unskilled workers and an increase of permanent skilled workers. Overall, companies utilize a smaller group of skilled workers, who are in charge of permanent duties, and a larger group of less skilled workers who perform time-bound tasks. This, ironically, is happening in spite of the fact that the production of high quality grapes has added many activities to be carried out throughout the year (green pruning, thinning, de-budding, water management, etc.), softening the otherwise stark seasonal profile of grape production. Companies have introduced new human resource management principles, considering these activities in atomized ways and executing them with workers hired ad-hoc for each task. By 2005, the grape industry employed $23 \%$ of its workforce as permanent workers and 77\% as temporary workers (Poblete 2012).

This new approach to production and the management of human resources has led companies to search for the most flexible forms to legally hire workers for limited periods and minimize labour costs. Different national legislation and agreements $^{3}$ offer a variety of legal figures in regulating temporary work, and classify workers as 'not permanent', 'seasonal', 'occasional' or 'discontinuous permanent'. These legal figures, often overlapping or complementing each other in the same productive unit, increase the complexity beyond the typical dichotomies between permanent/transitory and registered/non-registered workers. With the new tendency towards decreasing the number of low-skilled permanent workers, many contratistas have lost their jobs and have been offered the possibility of being re-hired as autonomous workers. For them, as well as for previously permanent workers, this is a deleterious change, since they

\footnotetext{
3 See the Collective Labour Agreement for the wine industry nr 154/91, Employment Contracts Law nr 20.744, and the Agricultural Work Law nr 22.248.
} 
have to deduct from their salary all contributions towards pension and health insurance and do not receive family allowances. Since these workers are now considered as independent providers of services, the relation between them and the vineyard owners is reduced to the exchange of the concrete service itself, eventually reducing the costs associated to the wage relation.

A similar strategy has been pursued through the externalization of hiring to labour contractors. This way, the only responsibility for the company is to pay the provider, while the latter is in charge of respecting the relevant legislation and of guaranteeing workers' rights. Different ways of organizing work, such as work crews, temporary work services and work cooperatives, are being used by employers with the purpose of saving on social contributions and increasing the distance between them and workers to avoid conflict. All these forms of work flexibilization are entirely legal - they were actually promoted by the state during the 1990s and have remained mostly untouched since then.

\subsubsection{Competition}

Competition assumes different forms depending on whether we examine the international or domestic wine markets. In the international market, Argentinean wine producers are essentially price-takers in a very competitive supply situation. Domestically, the most widely consumed product is still table wine. This segment is characterized by oligopsonistic competition: five major wineries are in control of winemaking, blending and commercialization of table wine and are among the few supply outlets for lower quality grape and wine producers. Thus, these big five wineries have important powers in determining prices. While the big wineries have some presence in the fine wine segment, their position is much weaker there because fine wine has a much more fragmented market with a growing number of competitors. Grape prices in the fine wine segment are not only higher, but also subject to more detailed negotiations between grape growers and wine producers, given that grape quality differences entail relatively larger premia and discounts over average prices.

\subsubsection{Money}

Transactions in the Argentinean wine industry are characterized by a high degree of informality, given that written contracts are not common. Usually, wineries buy grapes from their 'traditional' suppliers, but no agreements are reached before harvest. Especially in the quality-led regime of accumulation, the characteristics of the grape - which are of so much importance for the final wine - cannot be fully assessed until they have been harvested. Price negotiations begin only once the production has been delivered to the winery or even after samples of the wine can be evaluated. The system of payment in the wine industry varies depending on the kind of relationship between different players and the quality of the product. In the case of lower quality grapes, the dominant tendency for wineries is to pay their producers in a wage-like fashion - once the grapes have been delivered and the price agreed upon, the buyer pays for the total production in monthly installments throughout the following year. In the 
case of higher quality grapes, the landscape is more varied. While there is a tendency to pay in a shorter period of time, this is still done in three, six or nine months.

Possibilities for credit have been limited to local sources in the past decade, with options for international credit having been seriously curtailed after Argentina's debt default in 2002. Private options for credit are possible for bigger wineries and producers, but for smaller ones (the vast majority in Argentina) the conditions are too demanding. However, the provincial governments of Mendoza and San Juan, and the sectoral organization Argentinean Viniculture Corporation, have developed credit programmes targeting this group, with ad hoc funding by the Interamerican Bank for Development.

\subsubsection{State}

While the state had been an important actor in the wine industry until the end of the 1980s, the neoliberal policies of the 1990s considerably diminished the role of the state in the industry - although provincial governments are still involved in buying table wine and in determining production quotas to avoid oversupply. 'Sectoral governance' in Argentinean wine is the result of a process of negotiation between private actors (wineries, traders, grape producers and their respective interest organizations) and representatives of provincial governments and specialized state agencies. The Argentinean Viniculture Corporation, Wines of Argentina, and the Viniculture Fund have emerged as a result of these interactions. The clearest example of this public-private dynamic has been the development of the industry's roadmap known as the Argentinean Viniculture Strategic Plan 2020. This document was crafted jointly by representatives of grape and wine producers, exporters, universities and sectorspecific governmental agencies. Only after the most relevant players in the sector had reached an agreement, was it sent to the national congress for official endorsement. Thus, the most relevant policies and programmes developed for the wine industry are mostly driven by sector-specific organizations and by representatives of provincial governments, with national government being less relevant.

\subsubsection{International insertion}

This structural form is split along the same lines of the industry's regime of accumulation. The segment focused on production and commercialization of table wine targets mainly the domestic market, exporting only sporadically. The fine wine segment has always been export-oriented. However, exports are strongly determined by the mode of regulation of the overall economy. As noted earlier, the period between 2002-2009 witnessed a boom in exports due to the very competitive exchange rate adopted by the national government. But this situation has now begun to change due to: (1) a new exchange rate policy that has systematically attempted to avoid a devaluation (keeping the peso almost fixed at a relatively high rate); and (2) high levels of inflation that are increasing the costs of production. Since international prices have remained relatively stable, producers are experiencing a squeeze in margins, as they have not been 
able to adjust prices to reflect their growing production costs. In many cases, they have actually started diverting wine to the domestic market.

\subsection{Mode of regulation: Fair Trade wine}

\subsubsection{Wage relation}

There are two main dimensions worth examining to determine the potential of a Fair Trade mode of regulation to affect the wage relation: (1) how Fair Trade seeks to regulate work conditions; and (2) the so-called 'Fair Trade Premium'. In the case of the Argentinean wine industry, most of the requirements in the Fair Trade standard that affect the wage relation are already included in national or sector-specific regulations. Managers and administrative staff in certified organizations have unanimously pointed out that most of these requirements are regulated by law and that state and that labour unions in any case make only sporadic controls. Most of the requirements related to working conditions were indeed in place before Fair Trace certification was sought. An exception to this rule is the case of overtime, which - especially during the harvest season - has traditionally been used over and above the limits dictated by law. The harvest season demands large labour inputs in a very limited period of time. This leads to intensive and prolonged working days continuously for the two-three harvest months. While these working conditions have harmful effects, workers in the industry had come to count on those peak months to gain some extra income.

Minimum wages, no matter whether defined by collective bargaining or national law, are low in the wine industry, and that is why workers depend on overtime to achieve a living wage. Fair Trade requires wages to be set according to the national minimum wage, the collective bargaining agreement for the sector, or the regional average - whatever is higher. This means that Fair Trade expects the minimum wage to be legal, but does not consider its actual purchasing power. If Fair Trade wages were enough to cover basic needs, the restriction on extra hours would not be felt to the same extent. But since the Fair Trade wage is equal to the sectoral minimum wage, this leads to a lack of integrative income. This restriction has not been received well by management either, because of the difficult logistical conditions implied in rotating workers according to the maximum hours permitted. While smaller wineries have not had major problems with this situation, larger wineries are systematically asking for exceptions, which the certifying body has always granted.

Another relevant work condition in wine industry that is included in the Fair Trade standard relates to worker contracts. Fair Trade measures aiming at limiting sub-contracting and at raising the number of permanent workers are potentially positive, but have been applied unevenly. Subcontracting is allowed during the first year of the certification, and even after this period exceptions are often granted.

The second main element of relevance to the wage relation is the Fair Trade premium, an extra amount that the buyer pays on top of the agreed price. As the premium is assigned in proportion of the weight of grapes or volume of wine, its 
total amount does not vary with the price of the product but with the amount sold. Therefore, higher quantities of Fair Trade production will result in a higher amount of premium. In the case of small producer organizations, the Fair Trade premium can be used for any purpose, as long as the decision-making process is democratic. This makes it possible for producers to appropriate it as a sort of 'direct wage' or extra profit. The small producer organization researched for this project, for example, decided to create four general categories to distribute their premium funds: the functioning of the association (certification costs,

infrastructure, etc.); individual projects (according to each member's needs); an emergency fund; and a fund for the wider community.

In the case of hired labour situations, a much narrower set of alternatives are available because the Fair Trade standard does not allow benefits in the form of contributions to direct wages or investments related to maintaining certification. Therefore, most investments are directed towards the community. Nevertheless, this has been changing in time, with workers trying to find ways of using the premium to accrue benefits in the form of indirect wages. One of the strategies was designed at a winery in Mendoza, where a nutritionist was hired to develop a plan describing what a healthy and balanced diet would require according to the worker's characteristics. This plan was then used as the guideline to create a 'basket of healthy products' that was given to each of the 65 permanent workers. Since the standard does not allow the premium to be divided among workers in cash or kind, the strategy followed here was to frame this benefit within a wider educational/health concern.

A final aspect worth highlighting, common to both small producer organizations and hired labour situations, is the instability of the amount of Fair Trade premium, which is exposed to changes from year to year depending on volumes of Fair Trade production and sale. The Fair Trade premium, in other words, is pro-cyclical and ties the potential benefits for workers to the uncertainty of the conventional economy.

\subsubsection{Money}

Fair Trade clearly has no incidence on the macro-institutional conditions that shape the money form. However, there are three relevant aspects that Fair Trade seeks to regulate that are pertinent here: (1) the possibility of developing longterm contracts in which the conditions of exchange can be settled for a certain period of time and in advance; (2) the terms and conditions of payment involving Fair Trade products; and (3) the possibilities of credit and pre-financing that a Fair Trade mode of regulation may offer.

In the conventional wine industry in Argentina, most relationships between wineries and grape producers are informal, allowing the parties to step back at any time from their agreements. The possibility of signing long-term contracts would consolidate their relationship and provide more certainty to grape producers about the final price. The way in which Fair Trade attempts to do this is by requiring the buyer to provide the producer with a sourcing plan. In the case of grapes, this 'must cover each yearly harvest' and 'must be renewed a 
minimum of three months before they expire' (Fairtrade International, 2013: 10). Fair Trade's initial expectation of developing plans for 'several years' was thus reduced to a minimum period of three months in advance for the renewal the sourcing plan. In practice, this has been very loosely interpreted, with some wineries signing pre-contracts with final conditions (especially prices) settled at harvest time, the same situation as in the conventional wine sector.

A similar conclusion can be drawn by looking at the system of payments that Fair Trade has established. The generic standard for traders sets a maximum of 30 days after the invoice date to pay the Fair Trade minimum price and the Fair Trade premium. However, in practice, Fair Trade International has only sanctioned wineries when they have not paid the premium within 30 days, while it has been much more tolerant with delays in the payment for the product. In cases of intra-organizational payments, such as within a cooperative, no controls on payments are carried out and members are still being paid in twelve monthly installments.

Lastly, the Fair Trade standards provides the possibility for producers to demand up to 60 percent of the total contract as pre-finance, with the buyer being obliged to provide it at least six weeks before the shipment of the products. But the Argentinean wine industry already has a somewhat similar contractual form known locally as 'harvest and haulage advance payment'. This is usually agreed between the producer and the buyer, and the total amount is decided according to estimation of how much the producer would need in order to secure the harvest and transport of the commodity. While its total value does not usually reach 60 percent of the total commercialized production, interviews with grape producers suggest that it is still the main and only option in use.

\subsubsection{Competition}

Two aspects of competition are relevant to the discussion of the Fair Trade mode of regulation: (1) how Fair Trade prices are formed; and (2) how Fair Trade affects the way in which different firms organize their relations. The process of price formation in Fair Trade can be described as semi-administered, with minimum prices settled by the governing authority itself and levels on top of that regulated by the market. As explained in the standard, Fair Trade prices in the Argentinean wine industry vary according to the product. For grapes, the price consists of a minimum price defined by Fair Trade International (or the market price, whichever is higher) plus a premium. The minimum price for grapes is very appreciated, especially by small producers, since this industry has historically suffered a crisis of overproduction that pulled prices down to very low levels. In the case of wine, however, only a premium on top of the negotiated price is established. Therefore, both vertically integrated wineries and those buying Fair Trade wine negotiate its price according to the conditions in the conventional market.

While setting a minimum price for grapes is a major innovation in comparison to the conventional market, in Argentina's current context it has no impact on grape growers. The main reason is the country's steady inflation rate (estimated 
at over $20 \%$ since 2008 , except for 2009), which would require a permanent adjustment of the costs of production to determine the minimum price. But Fair Trade International has been unable to do so. The result is that all actors in the industry simply use market prices, which are much higher than the Fair Trade minimum price.

One of the main aspects of the Fair Trade mode of regulation is that the granting of the label allows certain products - and not others - access to the final market. Therefore, a Fair Trade certified wine does not compete directly with other wines, but is part of a different category. The entry barrier is set by the certification, with those not possessing it unable to sell their products as Fair Trade. However, this entry barrier is also constituted by Fair Trade's geography. An important ingredient of Fair Trade International's ideology is the division of the world in two hemispheres: the 'Global South' (producers) and the 'Global North' (consumers). This means that producers in wealthy countries are not allowed to apply for Fair Trade certification. If we superimpose Fair Trade's geography with the geography of wine, we can easily conclude that competition in Fair Trade wine is not only restricted by reducing the number of competing producer organizations, but also by reducing the number of countries of origin, something that benefits the small number of countries where Fair Trade certification of wine is allowed.

A second aspect altering competition is the logic on which it is based. Fair Trade allows its participants to escape the worst kinds of price-based competition (which is particularly disadvantageous for smaller producers) and to add other symbolic and differential quality features to their product, making it more competitive through other means. This way, Fair Trade represents a way of adding value, of making smaller producers interesting to potential buyers looking for such 'extra' features, and of escaping the conventional logic of competition.

At a first glance, Fair Trade thus innovates the competition norm in two ways: first, by reducing the number of competitors (both at the level of individual companies and countries of origin); and second, by shifting the main parameter on which competition is based from price to ethical attributes. However, this picture needs to be nuanced. First, many of the certified players are very large companies and/or local subsidiaries of international wine groups. Fair Trade, while creating a more restricted arena for competition, at the same time reproduces the hierarchies and inequalities of the conventional market. Second, while competition takes place within a differentiated 'ethical' sphere, price still plays an important part - many interviewees have pointed out that it is South Africa (with much lower prices, especially after a recent devaluation) that comfortably dominates the international market for Fair Trade wine.

\subsubsection{State}

Fair Trade, as many other sustainability/ethical certifications, works as a form of regulation designed and enforced by relevant private and civil society actors. It is supposed to be complementary to state regulation, since many of its attributes 
are similar: setting minimum conditions of work and production, inspecting whether these conditions are being respected, and sanctioning those who are not following the rules. But the state still has an important role in the Fair Trade mode of regulation for two main reasons: (1) it sets important parameters of reference for the development of standards; and (2) it can play an important role as a buyer in countries where alcohol monopolies still exist.

Several aspects of the Fair Trade standard are defined according to state-defined levels, such as wage levels, working hours, premium rates for payment of overtime, annual leave, maternity leave, social security provisions, and nonmonetary benefits (such as holidays, training, etc.). The regulation of areas used for grape production, and the possible applicability of the obligation for buyers to offer pre-finance are also set by the state. Fair Trade, for most issues, simply adopts state-set parameters as its own. Thus, on the one hand, Fair Trade ostensibly seeks to assume some of the responsibilities that the state does not assume, or inefficiently deals with. On the other hand, it does so by setting many of its standards on the basis of state regulation.

The second way of looking at the role of the state in the Fair Trade mode of regulation is to assess its incidence independently from the Fair Trade standard. The clearest instance in the wine industry is provided by alcohol state monopolies. Of particular relevance to Argentinean producers is the case of Sweden, which since 2006 has put out important tenders of Fair Trade certified wine. In Sweden, all purchases are done through the state monopoly, giving it enormous power in setting purchasing conditions. Requesting tenders for Fair Trade wine is a key contribution to the development of its global demand, promoted not so much by profit-oriented market conditions, but by a normative orientation. Thus, in this case, it is not Fair Trade that supports the state, but the (Swedish) state that supports Fair Trade.

\subsubsection{International insertion}

Fair Trade is tightly linked to international trade. Its idea has always been to support and empower producers in developing countries by achieving better exchange terms when exporting their production to richer societies. Therefore, Fair Trade is of main interest to actors that have the capacity to export and can offer a product that is of interest to importers and consumers in the 'Global North'. This means that it does not offer major advantages to actors who are not linked to the value chain producing fine wines for export. These actors have not been integrated into the now dominant regime of accumulation.

Out the current eleven Fair Trade certified actors, five are owned by foreign capital and belong to international wine groups. Out of the six remaining, one is a very large cooperative producing both table and fine wines, but which has had an international presence for many years. The three remaining wineries have gone through a process of conversion and now produce exclusively fine wines and target the international market. The last certified actor is a more diversified group of medium and small grape producers. This shows that Fair Trade has benefited mostly those actors that are part of the now dominant regime of 
accumulation of fine wines, while it has not provided meaningful opportunities for producers who are stuck in the segment of table wine for the domestic market.

\section{Conclusion}

Fair Trade presents itself as an alternative project seeking to improve the socioeconomic situation of small producers, workers and their families and communities. However, in the Argentinean wine sector it relies on the same overall logic of the conventional market. Fair Trade introduced some important innovations, especially the minimum price. But its impact depends on the context in which its standards are applied in practice. Fair Trade standards are beneficial for growers of certain products in particular societies, but they are far less incisive in other situations. A clear example is the minimum wage, which is not only different from country to country (according to national legislation), but also from sector to sector within the same country. Another example is working conditions, which often refer to locally or sectorally-set definitions.

In Argentina, Fair Trade can be seen as actually supporting the current transition towards a new and hegemonic regime of accumulation in the wine industry, contributing this way to the reproduction of its dominance. The wine industry in Argentina is currently divided between those who have converted to fine wines and those who have remained stuck in the production of table wines. Within this second group, we find the most vulnerable groups of producers, who face decreasing demand and unit prices. If Fair Trade were meant to support marginalized producers and workers, in Argentina it would have to target growers of grapes for table wine. But this has not been the case. Although a counter-tendency seems to be emerging, ${ }^{4}$ Fair Trade is still intrinsically linked to exports. And exporting requires the ability to engage in the production of fine wine. ${ }^{5}$ Our results confirm what Berlan and Dolan (2014: 54) term 'the double transgression of Fairtrade': although it emerged to moralize North-South economic relations, 'some of its efforts to do so have reproduced the alienation and detachment it once sought to address' (ibid., italics in the original). This does not mean that Fair Trade should be blamed for the existence of inequality and marginalization in the Argentinean wine industry - we have shown that these features are a result of the sector's own development in the context of broader changes in the economy. However, Fair Trade is responsible for contributing to the reproduction of these disparities, since the actors working with, and benefiting from, the Fair Trade mode of regulation are almost exclusively those that belong to the most dynamic and successful regime of accumulation.

\footnotetext{
${ }^{4}$ South Africa, Kenya, Mexico and Brazil are becoming not only places of Fair Trade production, but also consumption. In Argentina, FLO's local representatives would like to see the same development in domestic markets, but the size of the Fair Trade market in the country is for the time being very small.

5 While Fair Trade de facto excludes producers of table wine and low quality grapes, an alternative and plausible way of differentiating for these producers has been the production of so-called 'home-made' wines, which have developed independently in the aftermath of the 2001/2 crisis (Bocco and Brés 2010).
} 
The application of regulation theory to the wine industry in Argentina has shown that it allows a holistic understanding of Fair Trade as embedded in the broader economic system and its sectoral dynamics. This approach can thus usefully complement other analyses that articulate the role of quality regimes and quality conventions in the governance and restructuring of agro-food value chains. This suggests that there is a need to reinvigorate the regulationist and conventionalist research agenda proposed by Allaire and Boyer (1994), which has been relatively neglected in the past two decades.

\section{References}

Allaire, G. and R. Boyer (eds.) (1994) La grande transformation de l'agriculture. Paris: INRA Editions.

Artopoulos, A., D. Friel and J. Hallak (2010) Challenges of Exporting Differentiated Products to Developed Countries: The Case of SMEDominated Sectors in a Semi-Industrialized Country. IDB Working Paper Series No. IDB-WP-166.

Azpiazu, D. and E. Basualdo (2003) Estudios Sectoriales. Componente: Industria Vitivinícola. Buenos Aires: CEPAL-ONU.

Bacon, C. (2005) Confronting the Coffee Crisis: Can Fair Trade, Organic, and Specialty Coffees Reduce Small-Scale Farmer Vulnerability in Northern Nicaragua?, World Development 33(3): 497-511.

Barbera, F. and S. Audifredi (2012) In Pursuit of Quality: The Institutional Change of Wine Production Market in Piedmont, Sociologia Ruralis 52(3): 311-331.

Barrientos, S., Conroy, M. E. and Jones, E. (2007) Northern social movements and fair trade. In L.T. Raynolds, D. Murray and J. Wilkinson (Eds), Fair Trade: The Challenges of Transforming Globalization. London: Routledge, pp. 5162.

Bartoli, P. and D. Boulet (1990) Conditions d'une approche en termes de régulation sectorielle: Le cas de la sphère viticole. Cahiers d'économie et sociologie 17: 7-38.

Bek, D., C. McEwan and K. Bek (2007) Ethical trading and socioeconomic transformation: Critical reflections on the South African wine industry, Environment and Planning A 39: 301-319.

Berlan, A. and C. Dolan (2014) Of red herrings and immutables: Rethinking Faitrade ethid of relationality among cocoa producers. In M.K. Goodman and C. Sage (eds) Food transgressions: Making sense of contemporary food politics. Farnham: Ashgate, pp. 39-60.

Billaudot, B. (1996) L'ordre économique de la société moderne. Paris: L'Harmattan. 
Bocco, A., D. Dubbini, S. Rotondo and G. Yoguel (2007) Reconversión y empleo en la industria del vino: Estructura productiva y dinámica del empleo en el complejo vitivinícola. Paper presented at the $\mathrm{V}$ Jornadas Interdisciplinarias de Estudios Agrarios y Agroindustriales. Facultad de Ciencias Económicas, Universidad de Buenos Aires.

Boltanski 0. and L. Thévenot (1991) De la justification. Les économies de la grandeur. Paris: Gallimard.

Boyer, R. (1990) Les problématiques de la régulation face aux spécificités sectorielles: Perspectives ouvertes par la thèse de Pierre Bartoli et Daniel Boulet. Cahiers d'économie et sociologie 17: 39-76.

Boyer, R. (1990) The Regulation School: A Critical Introduction. New York: Columbia University Press.

Boyer, R. (2004) Théorie de la régulation. Paris: Éditions La Découverte.

Boyer, R. and Y. Saillard (2002) Un précis de la régulation. In R. Boyer and Y. Saillard (eds.) Théorie de la régulation: L'état des savoirs. Paris: Éditions La Découverte, 58-68.

Cusmano, L., A. Morrison and R. Rabellotti (2010) Catching up Trajectories in the Wine Sector: A Comparative Study of Chile, Italy, and South Africa, World Development 38(11): 1588-1602.

Dolan, C. (2010) Virtual moralities: The mainstreaming of Fairtrade in Kenyan tea fields, Geoforum 41(1) : 33-43.

Du Toit, A., Kruger S. and Ponte, S. (2008) Deracializing exploitation? 'Black economic empowerment' in the South African wine industry. Journal of Agrarian Change, 8(1): 6-32.

Eymard-Duvernay, F. (1989) Conventions de qualité et formes de coordination, Revue Economique 40(2), 329-359.

Eymard-Duvernay, F. (ed.) (2006a) L'économie des conventions, methodes et resultats. Tome 1: Débats. Paris: La Découverte.

Eymard-Duvernay, F. (ed.) (2006b) L'économie des conventions, methodes et resultats. Tome 2: Développements. Paris: La Découverte.

Fairtrade International (2013) Fairtrade Standard for Fresh Fruit for Hired Labour. Available online at: http://www.fairtrade.net/standards.html. Last accessed: 08/08/2013.

Freidberg, S. (2003) Culture, conventions and colonial constructs of rurality in south-north horticultural trades, Journal of Rural Studies 19(1): 97-109.

Freidberg, S. (2004) French beans and food scares: culture and commerce in an anxious age. New York: Oxford University Press. 
Gibbon, P. and S. Ponte (2005) Trading Down: Africa, Value Chains and the Global Economy, Philadelphia: Temple University Press.

Goodman, M.K. (2004) Reading fair trade: political ecological imaginary and the moral economy of fair trade foods, Political Geography 23(7): 891-915.

Goodman, M.K. (2010) The mirror of consumption: Celebritization, developmental consumption and the shifting cultural politics of fair trade, Geoforum 41(1): 104-116.

Guthey, G.T. (2008) Agro-industrial conventions: some evidence from northern California's wine industry, The Geographic Journal 174(2), 138-148.

Gwynne, R.N. (2006) Governance in the wine commodity chain: upstream and downstream strategies in New Zealand and Chilean wine firms, Asia Pacific Viewpoint 47(3): 381-395.

Hayward, D. and N. Lewis (2008) Regional dynamics in the globalising wine industry: The case of Marlborough, New Zealand, The Geographic Journal 174(2): 124-137.

Herman, A. (2010) Connecting the Complex Lived Worlds of Fairtrade, Journal of Environmental Policy \& Planning, 12(4): 405-422.

Herman, A. (2012) Tactical ethics: How the discourses of Fairtrade and Black Economic Empowerment change and interact in wine networks from South Africa to the UK, Geoforum 43: 1121-1130.

Jessop, B. (1997) Survey Article: The Regulation Approach, The Journal of Political Philosophy. 5(3): 287-326.

Kirwan, J. (2006) The interpersonal world of direct marketing: Examining conventions of quality at UK farmers' markets, Journal of Rural Studies 22: 301-312.

Kleine, D. (2008) Negotiating partnerships, understanding power: Doing action research on Chilean Fairtrade wine value chains, The Geographic Journal 174(2): 109-123.

Kruger, S. and A. du Toit (2007) Reconstructing fairness: Fair trade conventions and worker empowerment in South African horticulture. In L. T. Raynolds, D. L. Murray and J. Wilkinson (eds). Fair Trade: The Challenges of Transforming Globalization. London and New York: Routledge, pp. 200219.

Lacroix, A., A. Mollard and F. Bel (1994) L'approche sectorielle de la régulation: une problématique á partir de l'agriculture. In: La grande transformation de l'agriculture. Paris: INRA Editions, 259-291.

Laurent, C. and C. du Tertre (2008) Secteurs et territoires dans les régulations émergentes. Paris: L'Harmattan. 
Le Mare, A. (2008) The Impact of Fair Trade on Social and Economic Development: A Review of the Literature, Geography Compass 2(6): 192242.

Lindkvist, K. B. and J.L. Sánchez (2008) Conventions and Innovation: A Comparison of Two Localized Natural Resource-based Industries, Regional Studies 42(3): 343-354.

Lewis, N. (2008) Constructing economic objects of governance: the New Zealand wine industry. In C. Stringer and R. Le Heron (eds.) Agri-food commodity chains and globalising networks. Aldershot: Ashgate, 103-120

Lipietz, A. (1983) The Enchanted World: Inflation, Credit and the World Crisis. London: Verso.

Lipietz, A. (1988) Reflections on a Tale: The Marxist Foundations of Concepts of Regulation and Accumulation. Studies in Political Economy, 26: 7-36.

Mateu, A. (2007) El modelo centenario de la vitivinicultura mendocina: Génesis, desarrollo y crisis (1870-1980). In M. Delfini, D. Dubbini, M. Lugones, and I. Rivero (eds.) Innovación y empleo en tramas productivas de Argentina. Buenos Aires: Prometeo.

McEwan, C. and D. Bek (2006) (Re)politicizing empowerment: Lessons from the South African wine industry, Geoforum 37: 1021-1034.

McEwan, C. and D. Bek (2009a) The political economy of alternative trade: Social and environmental certification in the South African wine industry, Journal of Rural Studies 25: 255-266.

McEwan, C. and D. Bek (2009b) Placing ethical trade in context: Wieta and the South African Wine Industry, Third World Quarterly 30(4): 723-742.

Moseley, W.G. (2008) Fair Trade Wine: South Africa's Post-Apartheid Vineyards and the Global Economy, Globalizations 5(2): 291-304.

Murdoch, J. and M. Miele (1999) 'Back to nature': Changing 'worlds of production' in the food sector, Sociologia Ruralis 39(4): 465-483.

Murdoch, J., T. Marsden and J. Banks (2000) Quality, nature and embeddedness: some theoretical considerations in the context of the food sector, Economic Geography 76(2): 107-125.

Neffa, J. C. and D. Panigo (2010) Modelos productivos y sus impactos sobre la relación salarial. Reflexiones a partir del caso argentino. In E. de la Garza Toledo and J. Neffa (eds.) Trabajo y modelos productivos en América Latina, pp. 261-374. Buenos Aires: CEIL-PIETTE-CONICET / CLACSO / Casa Abierta al tiempo. 
Neiman, G. and A. Bocco (2001) Mercados de calidad y trabajo. El caso de la vitivinicultura Argentina. Paper presented at the $5^{\circ}$ Congreso Nacional de Estudios del Trabajo. 1-3 August 2011.

OIV (2009) Wine and Wine Outlook 2008-2009. OIV Statistical Publications. Available online at: http://www.oiv.int/oiv/files/OIVStatistiques20082009.pdf. Last accessed: 20/03/2014.

OIV (2011) Vine and Wine Outlook 2010-2011. OIV Statistical Publications. Available online at: http://www.oiv.int/oiv/files/4\%20$\% 20$ Statistiques/4\%20\%201\%20Publications\%20statistiques/OIV_Vine_and_Wine_Outlook_2010 -2011_EN.pdf. Last accessed: 20/03/2014.

Poblete, L. (2012) De trabajadores inamovibles a trabajadores móviles. El caso de los contratistas de una región vitícola de Mendoza, Argentina (19952010), Cuadernos de Relaciones Laborales 20(2) : 519-539.

Ponte, S. (2009) Governing through Quality: Conventions and Supply Relations in the Value Chain for South African Wine, Sociologia Ruralis 39(3): 236-257.

Ponte, S. and P. Gibbon (2005) Quality Standards, Conventions and the Governance of Global Value Chains, Economy and Society 34(1): 1-31.

Ponte, S. and T. Sturgeon (2014) Explaining Governance in Global Value Chains: A Modular Theory-building Effort, Review of International Political Economy 21(1): 195-223.

Raynolds, L.T. (2002) Consumer/producer links in fair trade coffee networks, Sociologia Ruralis 42(4): 404-424.

Raynolds, L.T. (2009) Mainstreaming Fair Trade Coffee: From Partnership to Traceability, World Development 37(6): 1083-1093.

Raynolds, L.T. (2012) Fair Trade: Social regulation in global food markets, Journal of Rural Studies 28: 276-287.

Raynolds, L.T., D. Murray and J. Wilkinson (eds.) (2007) Fair Trade: The challenge of transforming globalization. London: Routledge.

Renard, M.C. (2003) Fair trade: quality, market and conventions, Journal of Rural Studies 19(1): 87-96.

Rosin, C. and H. Campbell (2009) Beyond bifurcation: Examining the conventions of organic agriculture in New Zealand, Journal of Rural Studies 25: 35-47.

Sánchez-Hernández, J.L (2011) The food value chain as a locus for (dis)agreement: Conventions and qualities in the Spanish wine and Norwegian salted cod industries, Geografiska Annaler Series B, pp. 106-119. 
Sánchez-Hernández, J.L., J. Aparicio-Amador and J.L. Alonso-Santos (2010) The shift between worlds of production as an innovative process in the wine industry in Castile and Leon (Spain), Geoforum 41: 469-478.

Sylvander, B. (1995) Convention de qualité, concurrence et coopération: Cas du label rouge dans la filière volaille. In G. Allaire and R. Boyer (eds.) La grande transformation de l'agriculture. Paris: INRA-Economica, 73-96.

Thévenot, L. (1995) Des marchés aux normes. In G. Allaire and R. Boyer (eds.) La grande transformation de l'agriculture. Paris: INRA-Economica, 33-52.

Touzard, J. M. (1994) Régulation sectorielle, dynamique régionale et transformation d'un système productif localisé: exemple de la viniculture languedocienne. In G. Allaire and R. Boyer (eds.) La grande transformation de l'agriculture. Paris: INRA Editions, 293-322.

Touzard, J. M. (2009) Théorie de la Régulation et transformations agroalimentaires actuelles. Economies et sociétés 43(11): 1923-1933. 


\begin{tabular}{|c|c|c|c|c|}
\hline \multirow{2}{*}{$\begin{array}{l}\text { Wage } \\
\text { Relation }\end{array}$} & $\begin{array}{l}\text { Work } \\
\text { conditions }\end{array}$ & $\begin{array}{l}\text { - Flexibilization of work relations and } \\
\text { increase in contract work } \\
\text { - Most conditions defined by sectoral } \\
\text { collective bargain agreement (CBA) }\end{array}$ & $\begin{array}{l}\text { - Most working conditions are set } \\
\text { according to state or sectoral } \\
\text { regulation; minimum thresholds are } \\
\text { defined for some aspects }\end{array}$ & $\begin{array}{l}\text { - Most organizations already fulfill } \\
\text { regulations required by the state or } \\
\text { sectoral regulatory bodies } \\
\text { - In cases where the standard is } \\
\text { more demanding, many exceptions } \\
\text { have been granted }\end{array}$ \\
\hline & $\begin{array}{c}\text { Wage } \\
\text { determinant } \\
\mathrm{s}\end{array}$ & $\begin{array}{l}\text { - Direct wages: determined by CBA } \\
\text { - Indirect wages: partly determined by } \\
\text { CBA and the state }\end{array}$ & $\begin{array}{l}\text { - Direct and indirect wages: } \\
\text { determined by state of CBA } \\
\text { - Fairtrade Premium }\end{array}$ & $\begin{array}{l}\text { - Direct and indirect wages: } \\
\text { determined by CBA and/or the sate } \\
\text { - Fairtrade Premium: } \\
\text { indirect wage (hired labour) } \\
\text { direct 'wage' / profit (small } \\
\text { producer organizations) }\end{array}$ \\
\hline \multirow[b]{2}{*}{ Competition } & $\begin{array}{l}\text { Price } \\
\text { formation }\end{array}$ & $\begin{array}{l}\text { - Internal market: oligopsonistic price } \\
\text { formation } \\
\text { - World market: competitive pricing }\end{array}$ & $\begin{array}{l}\text { - Semi-administered process of price } \\
\text { formation (minimum price and } \\
\text { premium) }\end{array}$ & $\begin{array}{l}\text { - Weakened by the irrelevance of } \\
\text { the minimum price }\end{array}$ \\
\hline & $\begin{array}{c}\text { Form of } \\
\text { competition }\end{array}$ & $\begin{array}{l}\text { - Internal market: oligopsonistic } \\
\text { competition } \\
\text { - World market: price-based } \\
\text { competition within differentiated } \\
\text { qualities }\end{array}$ & $\begin{array}{l}\text { - Internal market: } \mathrm{n} / \mathrm{a} \text { (very small } \\
\text { market for fair trade wine) } \\
\text { - World market: element of 'ethical' } \\
\text { added value. }\end{array}$ & $\begin{array}{l}\text { - Internal market: } n / a \\
\text { - World market: price still plays an } \\
\text { important role in competition } \\
\text { between different Fair Trade wine } \\
\text { origins }\end{array}$ \\
\hline \multirow[t]{2}{*}{ Money } & $\begin{array}{l}\text { System of } \\
\text { payments }\end{array}$ & $\begin{array}{l}\text { - Informal agreements } \\
\text { - Wage-like ( } 12 \text { installments), especially } \\
\text { for supplies of low-quality grapes and to } \\
\text { cooperatives; fewer installments for } \\
\text { higher quality }\end{array}$ & $\begin{array}{l}\text { - Long-term relationships based in the } \\
\text { use of contracts and sourcing plans } \\
\text { (to be confirmed at least three months } \\
\text { before harvest) } \\
\text { - Payments made no more than } 30 \\
\text { days after the invoice date }\end{array}$ & $\begin{array}{l}\text { - No long-term relationships; } \\
\text { flexible application of the three- } \\
\text { month notice } \\
\text { - Very flexible application of rules; } \\
\text { payments rarely done within } 30 \\
\text { days }\end{array}$ \\
\hline & Credits & $\begin{array}{l}\text { - Limited possibility of credit for } \\
\text { investment } \\
\text { - Harvest and haulage advance payment } \\
\text { system (offered by buyers) }\end{array}$ & $\begin{array}{l}\text { - Pre-finance available for up to } 60 \% \\
\text { of the total contract value }\end{array}$ & $\begin{array}{l}\text { - Little use of pre-finance, only } \\
\text { conventional options applied }\end{array}$ \\
\hline \multirow[b]{2}{*}{ State } & $\begin{array}{l}\text { Rulemaking } \\
\text { role }\end{array}$ & $\begin{array}{l}\text { - Wider macroeconomic regulation by } \\
\text { national state } \\
\text { - Sector-level regulations, mostly by } \\
\text { provincial, sectoral and hybrid } \\
\text { institutions }\end{array}$ & $\begin{array}{l}\text { - National state as the parameter for } \\
\text { many aspects of the standard } \\
\text { - In case of contradiction between } \\
\text { state regulation and the Fair Trade } \\
\text { standard, the most demanding applies }\end{array}$ & $\begin{array}{l}\text { - Flexibility in favour of companies } \\
\text { by Fairtrade International in cases } \\
\text { where state regulations and Fair } \\
\text { Trade standards contradict each } \\
\text { other }\end{array}$ \\
\hline & As an actor & $\begin{array}{l}\text { - Much less involved than in the period } \\
\text { pre-1980 } \\
\text { - At the provincial level: possibility of } \\
\text { providing credit, buying wine } \\
\text { - Emergence of hybrid (private/public) } \\
\text { institutions }\end{array}$ & $\begin{array}{l}\text { - The state is not given any role as an } \\
\text { actor in the Fair Trade standard }\end{array}$ & $\begin{array}{l}\text { - Potentially important in creating } \\
\text { demand (e.g. state monopolies in } \\
\text { import markets) } \\
\text { - No involvement by the } \\
\text { Argentinean state. } \\
\text { - Exploratory interest by local } \\
\text { government in a few provinces }\end{array}$ \\
\hline \multicolumn{2}{|c|}{ International Insertion } & $\begin{array}{l}\text { - Main option for the dominant regime } \\
\text { of accumulation. } \\
\text { - Facing difficulties due to internal } \\
\text { inflation, fixed exchange rates and price } \\
\text { sensitive demand. }\end{array}$ & $\begin{array}{l}\text { - Historically, Fair Trade goods mainly } \\
\text { produced in the South and consumed } \\
\text { in the North } \\
\text { - In the past few years, efforts to } \\
\text { develop domestic markets for Fair } \\
\text { Trade products in the South }\end{array}$ & $\begin{array}{l}\text { - Fair Trade wine is exclusively } \\
\text { produced for the export market }\end{array}$ \\
\hline
\end{tabular}

Table 1 Conventional and Fair Trade modes of regulation in the Argentine wine industry 